\title{
Öğrencilerin Fen Bilimleri Dersine Yönelik Zihinsel İmajlarının Belirlenmesi: Bir Sınıflar Arası Karşılaştırma
}

\section{Unveiling Students' Mental Images of Science Course: A Cross-Grade Study}

\author{
Zeynep KIRYAK ${ }^{1}$, Bahar CANDAŞ ${ }^{2}$, Muammer ÇALIK ${ }^{3}$, Özlem ZEYBEK ${ }^{4}$
}

• Geliş Tarihi: 06.03.2019• Kabul Tarihi: 28.2.2020 • Çevrimiçi Yayın Tarihi: 05.05.2020

\section{$\ddot{O} z$}

Öğrencilerin fen bilimleri dersine yönelik görüşlerinin ortaya çıkarılması, öğretmenlerin onlarla etkili bir iletişim kurmasına ve uygun problem çözme stratejilerini gerçekleştirmesine imkân verecektir. Öğrencilerin fenne yönelik görüşlerini, algılarını, tutumlarını, beklentilerini ve önyargılarını dikkate alma, kavramsal öğrenmenin gerçekleşmesine ve akademik başarının artmasına katkı sağlayacaktır. Mevcudun yüksek ve zamanın kısıtlı olduğu sınıflarda kullanım kolaylığı sağlayan ve karmaşık kavramların ifade edilmesinde açık uçlu bir sorgulama yaklaşımı olan çizim yöntemi, öğrencilerin zihinsel imajlarının belirlenmesinde sıklıkla tercih edilmektedir. Çizimlerin ardından yapılacak sözlü veya yazılı açıklamalar öğrencilerin çizdikleri duruma yükledikleri anlamların açığa çıkarılmasına katkı sağlayacaktır. Bu bağlamda, çalışmanın amacı, beşinci, altıncı ve yedinci sınıf öğrencilerinin fen bilimleri dersine yönelik imajlarının çizimler ve yazılı açıklamalar aracılığıyla belirlenmesidir. Enlemsel araştırma yöntemi ile yürütülen çalışmaya, 45 beşinci, 19 altıncı ve 25 yedinci sınıf öğrencisi katılmıştır. Öğrencilerden Fen Bilimleri dersine yönelik düşüncelerini resmetmeleri ve çizdikleri resimleri yazılı olarak açıklamaları istenmiştir. Elde edilen bulgularda, öğrencilerin Fen Bilimleri dersini konu alanları, bilim insanları, öğretmen, öğrenme ortamı, derse yönelik duygu ve düşünceler gibi pek çok boyutla ilişkilendirdikleri belirlenmiştir. Bu tür çalışmaların, öğrencilerin derse yönelik kaygıları, beklentileri, ihtiyaçları veya kariyerlerinin planlanmasında öğretmenlere rehberlik edeceği düşünülmektedir.

Anahtar sözcükler: Fen bilimleri dersi, çizim yöntemi, öğrenci imajları.

Atıf:

Kıryak, Z., Candaş, B., Çalık, M. ve Zeybek, Ö. (2020). Öğrencilerin fen bilimleri dersine yönelik zihinsel imajlarının belirlenmesi: bir sınıflar arası karşılaştırma. Pamukkale Üniversitesi Eğitim Fakültesi Dergisi, 50, 468-490.doi: 10.9779/pauefd.536358

\footnotetext{
* Bu çalışma International Conference on Social Sciences and Humanities (ICSSH2016) adlı kongrede sözlü bildiri olarak sunulmuştur.

1 Arş. Gör., Trabzon Üniversitesi, Lisansüstü Eğitim Enstitüsü, ORCID: 0000-0002-8644-4336, zeynepkiryak@gmail.com

2 Arş. Gör., Trabzon Üniversitesi, Lisansüstü Eğitim Enstitüsü, ORCID: 0000-0003-4516-9670, bhrcnds@gmail.com

3 Prof. Dr., Trabzon Üniversitesi, Fatih Eğitim Fakültesi, ORCID: 0000-0001-8323-8783, muammer38@hotmail.com

${ }^{4}$ Fen Bilimleri Öğretmeni, İstanbul Fatih İslam Seçen Bilim ve Sanat Merkezi , ORCID: 0000-0002-2521-4393,

ozlem.zeybek16@gmail.com
} 


\begin{abstract}
Unveiling students' mental images of science course will give an opportunity for teachers to effectively communicate with them and conduct proper problem-solving strategies. Taking their views, perceptions, attitudes, expectations and prejudices of science course into consideration will contribute students' conceptual understanding and academic achievement levels. The drawing method, which is an open-ended questioning approach, is often preferred for determining students' mental images due to its efficiency in crowded classes, time-efficient and easily probing complex concepts. After the drawings, verbal or written explanations will make a contribution to discover what they meant. In this context, the study aimed to unveil the fifth, sixth and seventh grade students' mental images of the science course through drawings and writings. Through a cross-age study, a total of 79 students (45 for grade 5, 19 for grade 6 and 25 for grade 7) participated in the current study. The students were asked to draw their thoughts of the science course and explain their drawings. The findings indicated that the students tended to associate the science course with such aspects as subject areas, scientists, teachers, learning environment, and emotions and course thoughts. The current study recommends that future studies will guide teachers to elicit and work out students' concerns, expectations, career plans or needs.
\end{abstract}

Keywords: Science course, drawing method, mental images.

\title{
Cited:
}

Kıryak, Z., Candaş, B., Çalık, M. \& Zeybek, Ö. (2020). Unveiling students' mental images of science course: A cross-grade study. Pamukkale Üniversitesi Ĕgitim Fakültesi Dergisi, 50, 468-490.doi: 10.9779/pauefd.536358 


\section{Giriş}

Fen bilimleri dersi, fizik, kimya, biyoloji, astronomi, çevre gibi pek çok disiplini içinde barındırmaktadır. $\mathrm{Bu}$ nedenle, genellikle anlaşılması zor ve karmaşık dersler arasında görülmektedir. $\mathrm{Bu}$ karmaşıklığının yanında, fen bilimleri dersinin yüksek akademik başarı beklenen dersler arasında yer alması, öğrencilerin derse karşı olumsuz tutum geliştirmesine ve önyarg1 oluşturmasına sebep olmaktadır (Doğan, Oruncak ve Günbayı, 2002; Kızılcık, 2013; Oruncak, Ünal ve Özek, 2004). Öğrencilerin sahip olduğu bu önyargilar fen derslerine katılımlarını, dersi anlamalarını ve öğrenmelerini etkilemekte ve akademik başarı düzeylerini düşürmektedir (Devecioğlu ve Akdeniz, 2006; Mercer, Dawes ve Staarman, 2009). Bu nedenle, öğrenme öğretme ortamlarının öğrencilerin sahip oldukları bu tür ön yargıların giderilmesine, derse aktif katılımlarının sağlanmasına ve kavramsal öğrenmelerin gerçekleşebilmesine imkân verecek şekilde düzenlenmesi gerekmektedir. Diğer yandan, öğrenme ve öğretme ortamlarının düzenlenmesinde öğrencilerin çevreleriyle kurdukları iletişim ve etkileşim de büyük öneme sahiptir. Öğrencilerin öğretmenlerine, arkadaşlarına, derslere ve öğrenme ortamına yönelik alg1 ve gözlemlerinin belirlenmesi, onların öğrenme yaşantılarının geliştirilmesine katkı sağlayacaktır (Belet ve Türkan, 2007; Melanlıŏlu, 2015). Özellikle birçok öğrenci tarafından anlaşılması zor bir ders olarak kabul edilen fen bilimleri dersine yönelik öğrenci görüşlerinin ve yaşadıkları zorlukların anlaşılmasının onlarla etkili bir iletişimin kurulmasına zemin hazırlayacağı düşünülmektedir. Öğrencilerle iletişim kurabilen öğretmen onların sorunlarını anlama ve bunlara yönelik çözümler üretme firsatı bulabilecektir.

İletişim süreçlerinin büyük kısmında, bireyler kendilerini ifade etmede sözel ve yazılı dilin imkânlarından faydalanmaktadırlar. Bunun yanı sıra, öğrencilerin zihinlerindeki yapıların ortaya çıkarılmasında kavramsal anlama testleri, kelime ilişkilendirme testleri, iki aşamalı testler gibi farklı yöntemler kullanılabilmektedir. Özellikle küçük yaştaki öğrenciler, dil kapasitelerindeki yetersizliklerden dolayı düşüncelerini ifade etmekte çeşitli zorluklar yaşayabilmektedir. Aynı zamanda, bu öğrencilerin ifade etme şekillerinden dolayı, düşüncelerinin yanlış anlaşılabilme ihtimali bulunmaktadır. Dilsel açıdan daha yeterli olan büyük yaşlardaki öğrencilerle bile bireysel, toplumsal ve kültürel sebeplerden dolayı, etkili iletişim kurmada sıkıntılar yaşanabilmektedir (Barazza ve Robottom, 2008; Özdemir-Özden ve Özden, 2015). Bahsedilen sebeplerin etkisiyle öğrenciler kendilerini yeterince ifade etmekte zorlanmakta ya da düşüncelerini yargılanma korkusuyla açıcça belirtmekten kaçınabilmektedirler. Örneğin, öğrenciler görüşlerini bildirdiklerinde dahil oldukları grup tarafindan yargılanmamak ve soyutlanmamak için grubun düşüncesinden farklı bir görüşe sahip olsalar dahi, bunu saklama ihtiyacı duyabilmektedirler. Diğer yandan, düşüncelerini açıkça ifade etmekten çekinmese bile, kendisini nasıl ifade edeceğini bilmediğinden ya da sahip olduğu dilsel araçların yetersizliğinden görüşlerini olması gerektiğinden farklı ifade etmeleri söz konusu olabilmektedir. Bu tür durumlar, sözcük bilgileri ve araştırılan konuya yönelik kavramsal bilgi düzeyleri çerçevesinde, öğrencinin kendisini ifade etme yeterliğini ve biçimini etkilemektedir. Bu durumda, öğrencilerin kendini rahatlıkla ifade edebilmesi için çoğunlukla açık uçlu bir sorgulama yaklaşımı olarak çizimlerin kullanılması önerilmektedir (Aydoğdu ve Kesercioğlu, 2005; Harman, Aksan ve Çelikler, 2015). Böylece, çizimlerle öğrencinin zihnindeki bilgi, düşünce ve inançların hiçbir sınırlama olmadan açığa çıkarılma olasılığ mümkün olmaktadır (Özmen, 2005). Çizimler, düşüncelerini kelimelerle açıklamakta zorlanan bireyler için kullanılabilecek alternatif ve etkili bir yöntemdir (Bahar, Özel, Prokop ve Uşak, 
2008; Rodari, 2007). Öğrenciler, herhangi bir konu hakkındaki duygu ve düşüncelerini daha somut ve bütüncül bir bakış açısıyla, rahatlıkla ve samimi bir biçimde ifade edebilirler (Isbel ve Raines, 2012; Yavuzer, 2003). Ayrıca, çizimler, doğası gereği öğrenciler için yapıcı ve motive edici özelliğe sahip olup (Glynn, 1997), bireyin zekâ, endişe, tutum vb. durumları hakkında bilgi veren iletişimin başka bir şekli olarak görülmektedir (Zians, 1997).

Çizimle anlatım kelime seçimi, seçilen kelimelerin birbiriyle anlamlı ve tutarlı bir biçimde sıralanması gibi özellikleri olan yazılı veya sözlü metinlerden daha kolay ve eğlenceli bir iletişim yolu olarak görülmektedir (Akkuş, 2013; Haney, Russell ve Bebell, 2004). Böylece, kendini sanatsal bir faaliyetle anlatma firsatı bulan öğrencinin yaratıcılı̆̆ tanımlama gücü gelişir, özgüveni artar ve bu yolla öğrenme sürecine yönelik algısına ilişkin bir farkındalık kazanır (Efland 1995; Welch ve Greene 1995). Bir ders içerisinde yapılacak çizimler öğrencilerin anahtar kavramlarla ilgili zihinsel imajlarını açığa çıkarmaya yardımcı olacak etkinlikler olarak kabul edilmektedir. Aynı zamanda, çizimler başka bir metotla birlikte kullanıldığı zaman, öğrencilerin yaşantıları ile ilişkilendirip zihinlerinde yapılandırdıkları alternatif kavramlar derinlemesine tespit edilebilir (Driver, 1989; White ve Gunstone, 1992). Çizimler öğrencilerin bilgi, duygu, düşünce ve inanışlarını kelimelerden daha iyi ve etkili biçimde açıklayabilir. Bu bakış açısıyla, öğrenci çizimleri onların dünyayı nasıl algıladıklarına yönelik bilgi edinmede önemli bir kaynak olarak görülmektedir. Diğer yandan, çizim yönteminin birtakım sınırlılıkları bulunmaktadır. Çizimlerin yapılış sürecinde kullanılan imge ve semboller belirli kurallar ve ön bilgiler çerçevesinde şekillenmektedir. Kullanılan bu imge ve sembollerin öğrenci zihnindeki anlamı ve derinliği hakkında yorum yapmak ve çıkarımda bulunmak gerçeği yansıtmayan sonuçların elde edilmesine neden olabilir. Örneğin, bir öğrencinin "ev" çizmesi o öğrencinin "ev" ile ilgili olabilecek tüm bilgilere sahip olduğunu göstermemektedir. Bu çizim öğrencinin duygu, düşünce ve deneyimlerine göre şekillenmektedir (Rodari, 2007). Bu nedenle, çizimlerin derinlemesine incelenmesi için ek göstergelere ihtiyaç duyulmaktadır. Ayrıca, çizim yeteneğine güvenmeyen ya da çizdikleriyle kendisini yeterince ifade edemediğini düşünen öğrenciler aynı zamanda sözlü ve yazılı açıklama yapma ihtiyacı duyabilmektedir. Bu nedenle, çizimlerin ardından yapılacak sözlü ya da yazılı açıklamalar öğrencilerin belirlenen duruma kattığı anlamları açığa çıkarmak için önemli bilgiler sağlayacaktır (Einarsdottir, Dockett ve Perry, 2009).

Araştırmalarda çizimlerin, gerçekleştirilen öğretim uygulamalarının değerlendirilmesinde bir araç olarak kullanıldığı görülmektedir (Gülek, 1999; Chula, 1998). Çizim yönteminin öğrencilerin yazma, okuma ve konuşma becerilerinin gelişiminde bir öğretim stratejisi olarak kullanıldığı ve bu becerilerin gelişimini destekleyerek öğrencinin edindiği bilgilerin değerlendirilmesine de katkı sağladığı belirtilmektedir (Dülger, 2002; Malchiodi, 2005). Çizim yöntemi, sınıf mevcudunun yüksek, zamanın kısıtlı ve kavramların sözel olarak açıklanmasının karmaşık olduğu durumlarda etkili bir yöntem olarak önerilmesine rağmen (Glynn, 1997), öğrencilerin fen bilimleri dersine yönelik görüşlerinin çizimler aracılığıyla belirlenmesine yönelik olarak sınırlı sayıda çalışmanın bulunduğu görülmektedir. Kaplan (2011) tarafından ilköğretim 4.-8. sınıf öğrencileriyle fen ve teknoloji dersinde oluşturulan öğrenme ve öğretme ortamına dair öğrenci görüşlerinin çizim ve yazılı açıklamalarla belirlenmesine yönelik yürütülen çalışmada, tüm sınıf düzeylerinde öğretmenin bilgi aktaran rolünde resmedildiği ve geleneksel öğretim yöntemlerine işaret eden çizimlerin ve açıklamaların yapıldı̆̆ belirlenmiştir. Soysal ve Afacan (2012) ilköğretim öğrencilerinin 'fen ve teknoloji dersi' ve 'fen ve teknoloji 
dersi öğretmeni' kavramlarına yönelik metaforlarını belirleme amacıyla yürütülen çalışmada, öğrencilerin fen ve teknoloji öğretmenine yönelik metaforlarının bilgiyi aktarma biçimleri, bilgi sağlama ve her alanda bilgi sahibi kavramları temelinde şekillendiği ifade edilmiştir. Ulu (2012) tarafından, ilköğretim dördüncü ve beşinci sınıf öğrencilerinin fen ve teknoloji dersi öğretimine yönelik algılarının ve çoklu zekâ türleri arasındaki ilişkinin belirlenmesi amacıyla yürütülen çalışmada, fen bilgisi öğretmeninin resmedilmesi istenmiş ve çoklu zekâ alanları gözlem formları kullanılmıştır. Öğrencilerin çizimleri ve gözlem formlarından elde edilen verilerden, sözel zekâ türüne sahip öğrencilerin öğretmen merkezli; sosyal, doğa ve içsel zekâ türlerine sahip öğrencilerin ise öğrenci merkezli fen öğretimi algısına sahip oldukları belirlenmiştir. Ballıel-Ünal (2017) tarafindan dördüncü sınıf öğrencilerinin fen bilgisine yönelik algılarını belirlemek amacıyla yürütülen çalışmada, öğrencilerin büyük kısmının fen bilgisi kavramını sadece deney olarak yorumladıkları, kız öğrencilerin erkek öğrencilere oranla daha detaylı çizimler yaptıkları ortaya çıkmıştır. Ayrıca, araştırmada öğrencilerin fen bilgisini okul ve laboratuvar dışındaki ortamlarda yorumlayamadıkları belirlenmiştir. Dönmez (2017), ortaokul öğrencilerinin fen bilimleri ve fen bilimleri öğretmenine yönelik metaforik algılarını belirlemek amaciyla yürüttüğü çalışmada; öğrencilerin fen bilimlerini laboratuvar ve laboratuvar malzemeleriyle ilişkilendirdiklerini; fen bilimleri öğretmenini ise araştırmacı ve öğrenen olarak algıladıklarını ifade etmiştir.

Alanyazında, kişisel kimliğin bir yansıtıcısı olan çizimlerin eğitim araştırmalarında kullanılmasının hem öğretmenler hem de araştırmacılar için önemli veriler sağladığı görülmektedir. Öğrencilerin derse yönelik algıları, tutumları ve önyargıları öğretim sürecine katılımlarıyla doğrudan ilişkili olarak görülmektedir. Derse yönelik olumlu görüş ve tutuma sahip olan öğrenciler öğretim sürecinde fiziksel ve zihinsel olarak aktif olmayı tercih ederken, olumsuz görüş ve tutuma sahip olan öğrencilerin daha çok görev ve sorumluluk almaktan ve aktif katılım göstermekten kaçındıkları görülmektedir. Bu nedenle, öğrencilerin derse yönelik görüşlerinin açığa çıkarılmasının dersin yürütücüsü olan öğretmenin öğrenme ortamını ve süreçlerini tüm öğrencileri kapsayacak biçimde tasarlaması için önemli bir kaynak olarak görülmektedir (Toplu, 2015). Bu yolla, her bir öğrencinin derse yönelik olumlu tutum geliştirebileceği ve aktif katılım göstermeye istekli hale gelebileceği uygun öğretim yöntem ve tekniklerinin seçimiyle etkili öğrenme ortamları oluşturularak hem kavramsal öğrenmelerin gerçekleşmesi hem de akademik başarının artması desteklenebilir. Ancak, alanyazında yer alan çalışmalara bakıldığında, öğrencilerle yürütülen çalışmaların büyük kısmının fen bilimleri alanındaki belirli konu ve kavramlar üzerine öğrencilerin bilgi, akademik başarı ya da alternatif kavramlarını belirlemeye yönelik olduğu görülmektedir (Dikmenli, 2010; Eyceyurt-Türk vd., 2014; Harman vd. 2015; Nyachwaya vd., 2010; Özdemir-Özden ve Özden, 2015; Pekel ve Taştan-Kırık, 2016; Sadık, Çakan ve Artut, 2011; Uzunkavak, 2009). Fen bilimleri dersine ve öğrenme ortamına yönelik görüşlerin belirlendiği çalışmaların ise büyük kısmının öğretmen adayları ve öğretmenlerle yürütüldüğü görülmektedir (Alkış-Küçükaydın ve Uluçınar-Sağır, 2018; Elmas, Demirdöğen ve Geban, 2011; Yıldız-Feyzioğlu, Feyzioğlu ve Küçükçıng1, 2014). Öğrenme ortamının odak noktası olan öğrencilerin bu anlamda derse yönelik görüşlerinin belirlenmesinin önem arz ettiği düşünülmektedir. Fen bilimleri bağlamında bakıldığında, yapılan çalışmaların sonuçlarında öğrencilerin fen bilimlerine yönelik öğrenci algılarının belirlenmesinde ve elde edilen veriler doğrultusunda öğrencilerinin önyargılarının giderilmesinde çizim yönteminin etkili bir yol olduğu ifade edilmesine rağmen, bu amaca 
yönelik sınırlı sayıda çalışma yer almaktadır. Bu bağlamda, bu çalışmanın amacı, beşinci, altıncı ve yedinci sınıf öğrencilerinin fen bilimleri dersine yönelik imajlarının çizimler ve yazılı açıklamalar aracılığıyla belirlenmesidir.

\section{Yöntem}

Bireylerin zaman içindeki görüşleri, tutumları, inançları gibi özelliklerinin değişimi ve gelişiminin incelenmesi için alanyazında, enlemsel ve boylamsal olmak üzere iki yol önerilmektedir (Abraham, Williamson ve Westbrok, 1994; Gokdere ve Çalik, 2010). Enlemsel çalışmalar, bir grubun davranışlarını uzun süreli incelemek yerine aynı davranışın benzer gruplar üzerinden incelenmesi esasına dayanırken (Çepni, 2014), boylamsal çalışmalar aynı grubun zaman içindeki gelişiminin değerlendirilmesini sağlamaktadır (Çalık, Bektaş ve Coll, 2013). Her ne kadar boylamsal çalışmalar araştırmacılara, bireyin gelişimine yönelik daha gerçekçi bulgular sunsa da aynı veri toplama araçlarının belli bir süre boyunca tekrarlı olarak aynı gruba uygulanması, grubun veri toplama aracına ilgisinin azalması tehdidini içermektedir. Ayrıca, veri toplama sürecinin uzun sürmesi, örneklem kaybının yaşanma ihtimali, pahalı olması gibi güçlüklerinin olması boylamsal çalışmaların tercih edilmemesine sebep olmaktadır. Enlemsel çalışmalar ise, daha ucuz olması, zaman tasarrufu sağlaması, örneklem veri toplama aracı ilişkisinin tek seferlik olması ve veri kaybı olasılığının az olması gibi nedenlerle boylamsal çalışmalara iyi bir alternatif olmaktadır (Abraham vd., 1994; Çalık, Ültay, Kolomuç ve Aytar, 2015; Gokdere ve Çalik, 2010). Bu doğrultuda, bu çalışma beşinci, altıncı ve yedinci sınıf öğrencilerinin fen bilimleri dersine yönelik görüşlerini çizimler ve çizimlere yönelik yazılı açıklamalar aracılığıyla belirlemek amacıyla enlemsel araştırma yöntemi ile yürütülmüştür.

\section{Çalışma Grubu}

Araştırmaya 2015 - 2016 eğitim öğretim yılında İstanbul ilindeki orta sosyo-ekonomik düzeyden ailelerin yaşadığ bir bölgede yer alan bir ortaokulda eğitim öğretime devam eden 45 beşinci sınıf ( 20 erkek- 25 kız), 19 altıncı sınıf (13 erkek- 6 kız) ve 25 yedinci sınıf ( 9 erkek- 16 kı) öğrencisi katılmıştır. Araştırmanın uygulayıcılarından biri olan Fen Bilimleri öğretmeninin öğrencileri ile çalışıldığı için çalışma grubu kolay ulaşılabilir örneklem yöntemiyle seçilmiştir. Sekizinci sınıf öğrencileri, ortaöğretime geçiş merkezi sınavına hazırlandıkları için katılım göstermek istememişler ve bu nedenle araştırmaya dahil edilmemişlerdir.

\section{Çalışmada Kullanılan Ölçme Araçları ve Veri Analizi}

$\mathrm{Bu}$ çalışmada, öğrencilerden Fen Bilimleri dersine yönelik düşüncelerini resmetmeleri ve ardından çizdikleri resimleri yazılı olarak açıklamaları istenmiştir. Öğrencilerin çizdikleri resimler ve yazılı açıklamalar içerik analizi yöntemi ile iki araştırmacı tarafından analiz edilmiştir. Öğrencilerin çizimlerinde yer alan durumlar belirli temalar altında toplanarak kodlanmıştır. Elde edilen veriler frekanslarla tablolarda sunulmuştur. Ayrıca, öğrencilerin belirlenen kategorilere yönelik genel eğilimleri grafikler halinde sunulmuştur. Her sınıf düzeyinde farklı sayıda öğrenci bulunduğu için grafiklerdeki dağılımlar yüzde cinsinden ifade edilmiştir. Yapılan analizler bir alan eğitimcisi (kimya eğitimi) tarafından incelenmiştir ve araştırmacılar arası kodlama uyumu \%96 olarak hesaplanmıştır (Miles ve Huberman, 2015). 


\section{Bulgular}

Ortaokul öğrencilerinin fen bilimlerine yönelik görüşlerinin belirlenmesi amaciyla yürütülen bu çalışmada, öğrencilerin çizimleri ve yazılı açıklamaları sınıf düzeylerine göre tablolaştırılmıştır. Öğrencilerin cevaplarındaki değişimi belirlemek için açığa çıkan kategoriler karşılaştırılarak sunulmuştur. Tablo 1'de öğrencilerin fen bilimleri derisine yönelik çizimlerinden elde edilen bulgular sunulmuştur.

Tablo 1. Öğrencilerin Fen Bilimleri Dersine Yönelik Çizimleri

\begin{tabular}{|c|c|c|c|c|c|c|c|}
\hline \multirow{2}{*}{ Kategori } & \multirow{2}{*}{ Kodlar } & \multicolumn{2}{|l|}{ 5. sinif } & \multicolumn{2}{|l|}{ 6. sinif } & \multicolumn{2}{|l|}{ 7. sinif } \\
\hline & & ÖK & f & ÖK & f & ÖK & f \\
\hline & & $\begin{array}{l}\text { Ö18, Ö28, Ö31, } \\
\text { Ö32, Ö41, Ö43 }\end{array}$ & 6 & $\begin{array}{l}\text { Ö14, Ö16, } \\
\text { Ö19 }\end{array}$ & 3 & Ö11 & 1 \\
\hline & Bireysel çalışma & $\begin{array}{l}\text { Ö1, Ö25, Ö29, } \\
\text { Ö31, Ö36 }\end{array}$ & 5 & Ö16 & 1 & Ö3 & 1 \\
\hline & $\begin{array}{l}\text { Laboratuvar } \\
\text { malzemeleri }\end{array}$ & $\begin{array}{l}\text { Ö33, Ö39, Ö44, } \\
\text { Ö45 }\end{array}$ & 4 & - & - & - & - \\
\hline & Güvenlik önlemleri & Ö17, Ö18, Ö43 & 3 & Ö16 & 1 & - & - \\
\hline & Grup çalışması & Ö2, Ö39, Ö44 & 3 & - & - & - & - \\
\hline & Bilim insanı & Ö18, Ö37 & 2 & Ö4, Ö6 & 2 & Ö11, Ö24 & 2 \\
\hline & Tehlikeli deneyler & Ö31 & 1 & Ö14, Ö15 & 2 & - & - \\
\hline & İcatlar & Ö25 & 1 & & - & - & \\
\hline \multirow{3}{*}{ 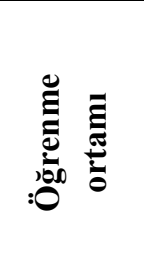 } & $\begin{array}{l}\text { Geleneksel sınıf } \\
\text { düzeni }\end{array}$ & Ö3, Ö10 & 2 & - & - & - & - \\
\hline & Öğretmen merkezli & Ö32, Ö41 & 2 & - & - & - & - \\
\hline & $\begin{array}{l}\text { aktarımı, Öğrenci } \\
\text { merkezli, Sinavlarda } \\
\text { rekabet) }\end{array}$ & Ö22 & 1 & Ö5 & 2 & Ö11 & 1 \\
\hline \multirow{8}{*}{ 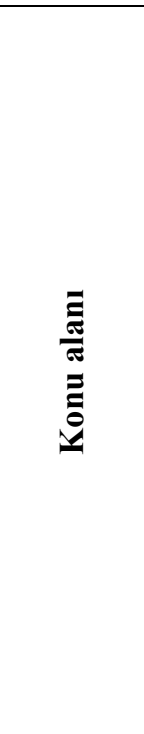 } & Kimya & $\begin{array}{l}\text { Ö1-6, Ö8, Ö9, } \\
\text { Ö11, Ö12, Ö15- } \\
\text { 18, Ö20, Ö23-27, } \\
\text { Ö29-33, Ö35-38, } \\
\text { Ö41, Ö45 }\end{array}$ & 31 & $\begin{array}{l}\text { Ö5, Ö6, Ö7, } \\
\text { Ö8, Ö12, } \\
\text { Ö14, Ö15, } \\
\text { Ö16, Ö18, } \\
\text { Ö19 }\end{array}$ & 10 & $\begin{array}{l}\text { Ö5, Ö7-13, } \\
\text { Ö15, Ö16, } \\
\text { Ö19, Ö20, } \\
\text { Ö22, Ö25 }\end{array}$ & 14 \\
\hline & Biyoloji & $\begin{array}{l}\text { Ö14, Ö19, Ö28, } \\
\text { Ö29, Ö34, Ö38, } \\
\text { Ö42, Ö45 }\end{array}$ & 8 & $\begin{array}{l}\text { Ö1-5, Ö7, } \\
\text { Ö9-11, Ö13, } \\
\text { Ö17, Ö19 }\end{array}$ & 12 & $\begin{array}{l}\text { Ö1, Ö2, Ö4, } \\
\text { Ö6-8, Ö10, } \\
\text { Ö14, Ö18, } \\
\text { Ö19, Ö21, } \\
\text { Ö22, Ö24, Ö25 }\end{array}$ & 14 \\
\hline & Fizik & $\begin{array}{l}\text { Ö4, Ö5, Ö9, Ö10, } \\
\text { Ö21, Ö26, Ö30, } \\
\text { Ö33, Ö38 }\end{array}$ & 9 & Ö5, Ö7, Ö17 & 3 & $\begin{array}{l}\text { Ö3, Ö7-9, Ö17, } \\
\text { Ö19 }\end{array}$ & 6 \\
\hline & Astronomi & Ö6, Ö7, Ö38, Ö45 & 4 & - & - & Ö7, Ö22, Ö25 & 3 \\
\hline & Doğa & Ö37, Ö42 & 2 & - & - & Ö10, Ö13, Ö25 & 3 \\
\hline & Günlük hayat & Ö13, Ö40 & 2 & - & - & - & \\
\hline & Matematik & - & - & - & - & Ö8, Ö11 & 2 \\
\hline & Soyut çizim & - & - & - & - & $\mathrm{O} 23$ & 1 \\
\hline
\end{tabular}

Tablo 1 incelendiğinde, beşinci, altıncı ve yedinci sınıf öğrencilerinin çizimlerinin laboratuvar, öğrenme ortamı ve konu alanı kategorisi altında toplandığı görülmektedir. Konu alanı kategorisi altında, beşinci sınıf öğrencilerinin kimya alanını temel alan çizimlere daha sık 
yer verdikleri $(n=31)$, fizik $(n=9)$ ve biyoloji $(n=8)$ alanına yönelik çizim yapan öğrenci sayısının ise kimya alanına göre oldukça düşük frekanslarda açığa çıktığı belirlenmiştir. Altıncı sınıf öğrencilerinin bu kategori altındaki cevaplarına bakıldığında, 12 öğrencinin biyoloji ve 10 öğrencinin kimya kodlarına uygun çizimler yaptıkları görülürken, yedinci sınıf düzeyinden 14'er öğrencinin kimya ve biyoloji alanlarına yönelik, 6 öğrencinin ise fizik alanına yönelik çizimler yaptıkları belirlenmiştir. Laboratuvar kategorisinde yer alan kodlara bakıldığında, beşinci sınıf öğrencilerinin deney yapma $(n=6)$ ve bireysel çalışma $(n=5)$ kodlarına uygun çizim yaptıkları, altıncı ve yedinci sınıf seviyelerinde ise bu kategoriye uygun çizimlerinin az sayıda olduğu görülmüştür.

Öğrencilerin laboratuvar, konu alanı ve öğrenme ortamı kategorilerine yönelik olarak yaptıkları çizim örnekleri Şekil 1, Şekil 2 ve Şekil 3'te sunulmuştur.

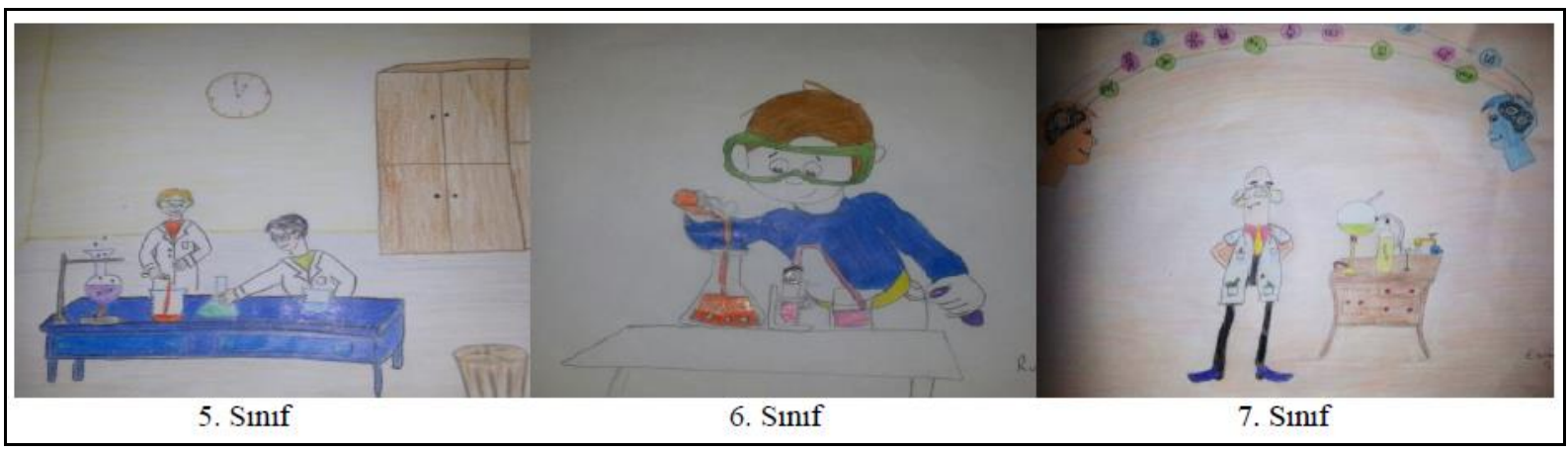

\section{Şekil1. Laboratuvar kategorisine yönelik çizim örnekleri}

Şekil 1'den görüldüğü gibi beşinci sınıf düzeyindeki öğrenci laboratuvarda öğretmenle birlikte deney yapıldığını çizerken, altıncı sınıf düzeyindeki öğrenci tek başına deney yapabilen bir öğrenciyi resmetmiştir. Yedinci sınıf öğrencisi ise bir bilim insanının laboratuvar çalışmalarını ve bilgi aktarımını çizmiş̧ir. Bununla birlikte, güvenlik önlemlerine yönelik de çizimlerin yer aldığı dikkat çekmektedir.

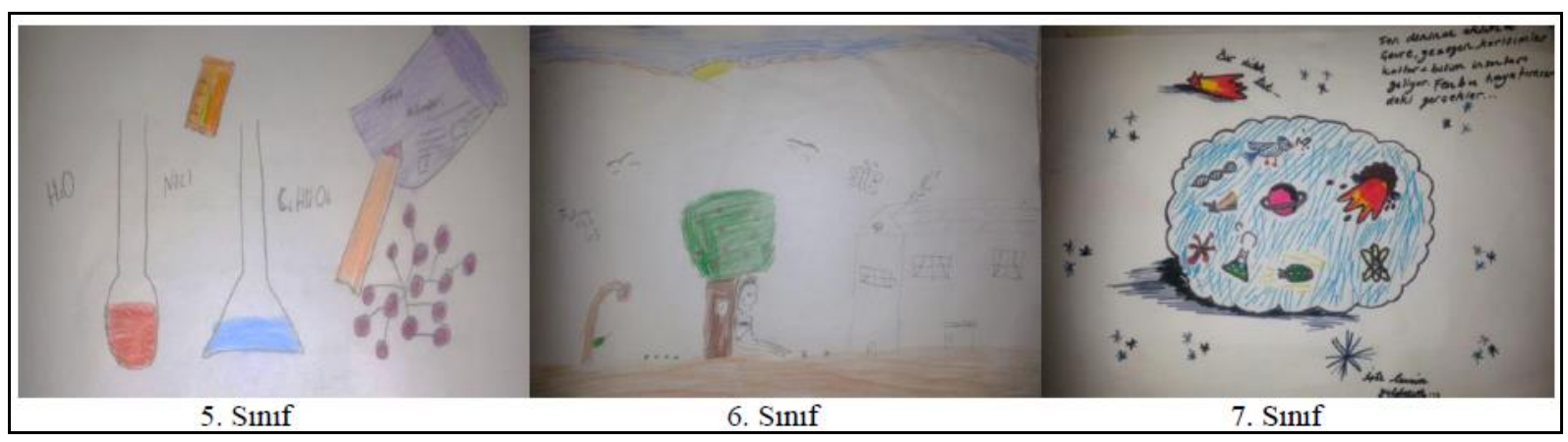

\section{Şekil2. Konu alanı kategorisine yönelik çizim örnekleri}

Şekil 2'ye bakıldığında, konu alanı kategorisinde yapılan çizimlerin beşinci sınıf düzeyinde kimya konuları ve kimyasal maddeler ile ilgili olduğu görülmektedir. Altıncı sınıf düzeyindeki öğrencinin Newton'un yerçekimini keşfediş hikayesini resmettiği belirlenirken, yedinci sınıf düzeyindeki öğrencinin astronomi, biyoloji, kimya gibi fen bilimleri dersinin altında yer alan çeşitli konuları içeren bir çizim yaptığı görülmektedir. 


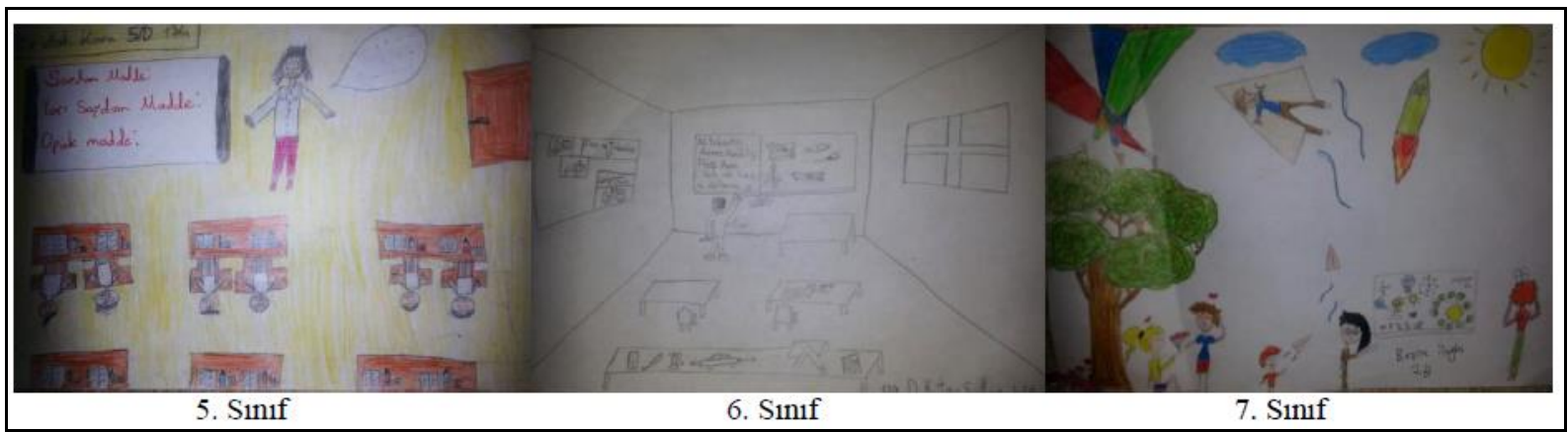

\section{Şekil3. Öğrenme ortamı kategorisine yönelik çizim örnekleri}

Şekil 3'teki öğrenme ortamı kategorisine yönelik çizim örneklerine bakıldı̆̆ında, beşinci sınıf düzeyindeki öğrencinin öğretmenin bilgi aktaran rolünde olduğu geleneksel sınıf düzenini resmettiği, altıncı sınıf düzeyindeki öğrencinin daha etkileşimli bir sınıf ortamı çizdiği, yedinci sınıf düzeyindeki öğrencinin ise öğrenmenin okul dışı ortamlarda gerçekleşebileceğini resmettiği belirlenmiştir.

Öğrencilerin çizimlerine yönelik yaptıkları yazılı açıklamalardan elde edilen veriler Tablo 2 'de sunulmuştur. 
Öğrencilerin Fen Bilimleri Dersine Yönelik Zihinsel İmajlarının Belirlenmesi: Bir Sınıflar Arası Karşılaştırma 477

Tablo 2. Öğrencilerin Fen Bilimleri Dersine Yönelik Yaptıkları Çizimlerin Açıklamaları

\begin{tabular}{|c|c|c|c|c|c|c|c|c|}
\hline \multirow{2}{*}{ Kategori } & \multirow{2}{*}{ Kodlar } & \multicolumn{2}{|l|}{ 5. sinıf } & \multicolumn{2}{|l|}{ 6. sinif } & \multicolumn{2}{|c|}{ 7. sinif } & \multirow{2}{*}{ Örnek açıklamalar } \\
\hline & & ÖK & $\mathbf{f}$ & ÖK & $\mathbf{f}$ & ÖK & f & \\
\hline & & Ö1, Ö16 & 2 & - & - & - & - & \multirow{9}{*}{$\begin{array}{l}\text { Ö9 - Fen dersinde bilim ve araştırma olur } \\
\text { genellikle ve matematik işlemi de } \\
\text { görülebilir. (5. Sınıf) } \\
\text { Ö14 - Fen dersi bana laboratuvarı anlatıyor. } \\
\text { Laboratuvarda olan deneylerin patlamasını } \\
\text { ve deneylerin yeniden yapılmasını anlatıyor. } \\
\text { (6. Sınıf) } \\
\text { Ö3 - Fen denilince aklıma laboratuvar } \\
\text { geliyor. Bu resimde mikroskopla uğraşan } \\
\text { (deney) adamlar görüyoruz. (7. Sınıf) } \\
\text { Ö16 - Geçmişte bilim adamları molekül, aşı, } \\
\text { basınç vb. lerini bulmuşlardır. Çoğu bilim } \\
\text { adamımız rastlantı sonucu ile bazı şeyler } \\
\text { bulmuşlardır. Deneylerde insanların } \\
\text { bilmediği bazı şeyler çıkar. (7. Sınıf) }\end{array}$} \\
\hline & $\begin{array}{l}\text { Laboratuvar } \\
\text { malzemeleri }\end{array}$ & $\begin{array}{l}\text { Ö2, Ö4, Ö9, } \\
\text { Ö11, Ö12, Ö15- } \\
\text { 17, Ö20, Ö28, } \\
\text { Ö29, Ö31-33, } \\
\text { Ö36, Ö38, Ö41, } \\
\text { Ö43, Ö44 } \\
\text { Ö30, Ö31, Ö33, } \\
\text { Ö35, Ö39, Ö41 }\end{array}$ & 19 & $\begin{array}{l}\text { Ö2, Ö4, Ö6, } \\
\text { Ö8, Ö10, Ö14, } \\
\text { Ö18, Ö19 }\end{array}$ & 8 & $\begin{array}{l}\text { Ö13, Ö16, } \\
\text { Ö23 }\end{array}$ & 3 & \\
\hline & Bilim insanları & Ö18, Ö41 & 2 & Ö6, Ö10, Ö19 & 3 & $\begin{array}{l}\text { Ö3, Ö16, } \\
\text { Ö22, Ö24 }\end{array}$ & 4 & \\
\hline & \multirow{7}{*}{$\begin{array}{l}\text { Tehlikeli deneyler } \\
\text { Araştırma } \\
\text { Laboratuvarda ders } \\
\text { işleme } \\
\text { Güvenlik önlemleri } \\
\text { alabilme } \\
\text { Bilim } \\
\text { Diğerleri (Keşfetme } \\
\text { vb.) }\end{array}$} & Ö11, Ö31, Ö45 & 3 & Ö14 & 1 & - & - & \\
\hline & & Ö9, Ö37, Ö43 & 3 & - & - & - & - & \\
\hline & & Ö4, Ö27 & 2 & Ö14, Ö19 & 2 & - & - & \\
\hline & & Ö15, Ö31 & 2 & - & - & - & - & \\
\hline & & Ö9 & 1 & Ö2, Ö12 & 2 & Ö13 & 1 & \\
\hline & & - & - & Ö15, Ö19 & 2 & Ö3, Ö20 & 2 & \\
\hline Toplam & & & 40 & & 18 & & 10 & \\
\hline & Öğretmen merkezli & Ö32 & 1 & Ö4 & 1 & - & - & \multirow[b]{2}{*}{$\begin{array}{l}\text { Ö32 - Fen bilimlerinde öğretmenimiz bize } \\
\text { laboratuvarda bir şeyler anlatır. (5. Sınıf) } \\
\text { Ö29 - Fen dersindeki deneyleri inceleyip } \\
\text { bakıyorum. Bazen ben de deney yapıyorum. } \\
\text { (5. Sınıf) } \\
\text { Ö4 - Fen dersinde fen öğretmeni vardır ve } \\
\text { deneyler vardır. Öğretmen öğrencilerine deney } \\
\text { anlatır. Öğrenciler de bilim öğrenmek için } \\
\text { öğretmeni dinler. (6. Sınıf) }\end{array}$} \\
\hline $\begin{array}{c}\text { Öğrenme } \\
\text { ortamı }\end{array}$ & Öğrenci merkezli & Ö29 & 1 & - & - & - & - & \\
\hline
\end{tabular}




\begin{tabular}{|c|c|c|c|c|c|c|c|c|}
\hline Toplam & & & 2 & & 1 & & - & \\
\hline \multirow{8}{*}{ 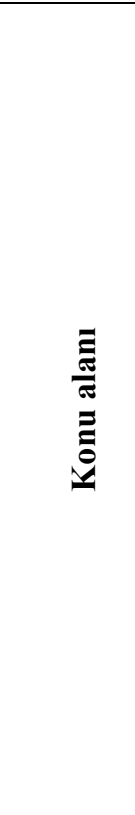 } & Kimya & $\begin{array}{l}\text { Ö3, Ö6-8, Ö12, } \\
\text { Ö15, Ö25, Ö33, } \\
\text { Ö34, Ö41, Ö42 }\end{array}$ & 11 & - & - & $\begin{array}{l}\text { Ö3, Ö5, Ö7, } \\
\text { Ö9, Ö10, } \\
\text { Ö15, Ö19, } \\
\text { Ö20, Ö22 }\end{array}$ & 9 & \multirow{8}{*}{$\begin{array}{l}\text { Ö5 - İlkokulda fen abana açıkçası çok zor } \\
\text { gelmişti... bildiğim şeylerden biri elektrik } \\
\text { devresi yapmaktı. Elektrik devresi yapınca } \\
\text { fen bana daha eğlenceli geldi. (6. Sınıf) } \\
\text { Ö1 - Fen denilince aklıma canlılarda olan } \\
\text { hücreler ve DNA'lar geliyor. Çünkü her } \\
\text { tarafa baktığımızda vardır. Canlıların içinde } \\
\text { de DNA, hücre vardır. (7. Sınıf) } \\
\text { Ö13 - Fen bilimleri canlı cansız doğa ile } \\
\text { ilgilenmektedir. İnsanlar, bitki ve } \\
\text { hayvanların yaşamını ögreniriz. Fiziksel } \\
\text { çevreyi tanırız. Deneyler yapılır. (7. Sınıf) }\end{array}$} \\
\hline & Fizik & $\begin{array}{l}\text { Ö12, Ö25, Ö33, } \\
\text { Ö36, Ö38, Ö39, } \\
\text { Ö41, Ö42 }\end{array}$ & 8 & Ö5, Ö17 & 2 & $\begin{array}{l}\text { Ö3, Ö5, Ö7, } \\
\text { Ö9, Ö10, } \\
\text { Ö17, Ö19 }\end{array}$ & 7 & \\
\hline & Biyoloji & $\begin{array}{l}\text { Ö26, Ö27, Ö34, } \\
\text { Ö36, Ö38, Ö42 }\end{array}$ & 6 & $\begin{array}{l}\text { Ö1, Ö2, Ö7, } \\
\text { Ö9, Ö10, Ö17, } \\
\text { Ö19 }\end{array}$ & 7 & $\begin{array}{l}\text { Ö1, Ö4, Ö6, } \\
\text { Ö7, Ö10, } \\
\text { Ö14 Ö16, } \\
\text { Ö18, Ö19, } \\
\text { Ö21 }\end{array}$ & 10 & \\
\hline & Astronomi & $\begin{array}{l}\text { Ö6, Ö7, Ö27, } \\
\text { Ö38, Ö42 }\end{array}$ & 5 & - & - & Ö22 & 1 & \\
\hline & Bilim & $\begin{array}{l}\text { Ö3, Ö9, Ö22, } \\
\text { Ö38, Ö39 }\end{array}$ & 5 & - & - & - & - & \\
\hline & Doğa & - & & - & & $\begin{array}{l}\text { Ö5, Ö13, } \\
\text { Ö22 }\end{array}$ & 3 & \\
\hline & Teknoloji & Ö26, Ö42 & 2 & - & - & Ö5, Ö15 & 2 & \\
\hline & İcatlar & - & - & - & - & Ö22 & 1 & \\
\hline Toplam & & & 37 & & 9 & & 33 & \\
\hline \multirow{5}{*}{ 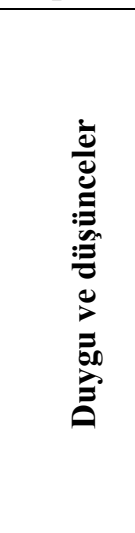 } & Fenni sevme & $\begin{array}{l}\text { Ö5, Ö10, Ö11, } \\
\text { Ö20, Ö25, Ö31, } \\
\text { Ö32, Ö37-39, } \\
\text { Ö45 }\end{array}$ & 11 & Ö3, Ö5, Ö13 & 3 & Ö25 & 1 & \multirow{5}{*}{$\begin{array}{l}\text { Ö12 - Karlı bir günde arabamızın tekerleğine } \\
\text { zincir takmazsak arabalarımız kayar ve } \\
\text { ölebiliriz. (5. Sınıf) } \\
\text { Ö29 - Fen deyince aklıma bilim geliyor, } \\
\text { sinav geliyor. Fen bilimleri çok eğlenceli bir } \\
\text { ders. (5. Sınıf) } \\
\text { Ö32 - Yaptığım resimde fen dersinin ne } \\
\text { kadar önemli olduğunu açıklamak istedim. } \\
\text { Fen dersinin güzel yönlerinde en çok } \\
\text { laboratuvara gidip deney yapmak ve } \\
\text { eğlenmek aklımda kalıyor. (5. Sınıf) } \\
\text { Ö3 - Fen dersi önemli bir derstir. İnsana }\end{array}$} \\
\hline & $\begin{array}{l}\text { Hayatla ilgili şeyleri } \\
\text { öğrenme }\end{array}$ & Ö12, Ö21, Ö37 & 3 & $\begin{array}{l}\text { Ö2, Ö3, Ö7, } \\
\text { Ö11, Ö15 }\end{array}$ & 5 & $\begin{array}{l}\text { Ö3, Ö5, Ö6, } \\
\text { Ö8, Ö16, } \\
\text { Ö22, Ö23 }\end{array}$ & 7 & \\
\hline & $\begin{array}{l}\text { Dersi eğlenceli } \\
\text { bulma }\end{array}$ & $\begin{array}{l}\text { Ö3, Ö5, Ö22-24, } \\
\text { Ö29, Ö30 }\end{array}$ & 7 & Ö5, Ö15 & 2 & Ö23, Ö25 & 2 & \\
\hline & Derse önem verme & $\begin{array}{l}\text { Ö29, Ö32, Ö37, } \\
\text { Ö45 }\end{array}$ & 4 & $\begin{array}{l}\text { Ö3, Ö7, Ö11, } \\
\text { Ö16 }\end{array}$ & 4 & $\begin{array}{l}\text { Ö2, Ö5, } \\
\text { Ö10, Ö12, } \\
\text { Ö23, Ö24 }\end{array}$ & 6 & \\
\hline & Yeni şeyler & Ö4, Ö5, Ö38, & 5 & Ö2, Ö15 & 2 & - & - & \\
\hline
\end{tabular}




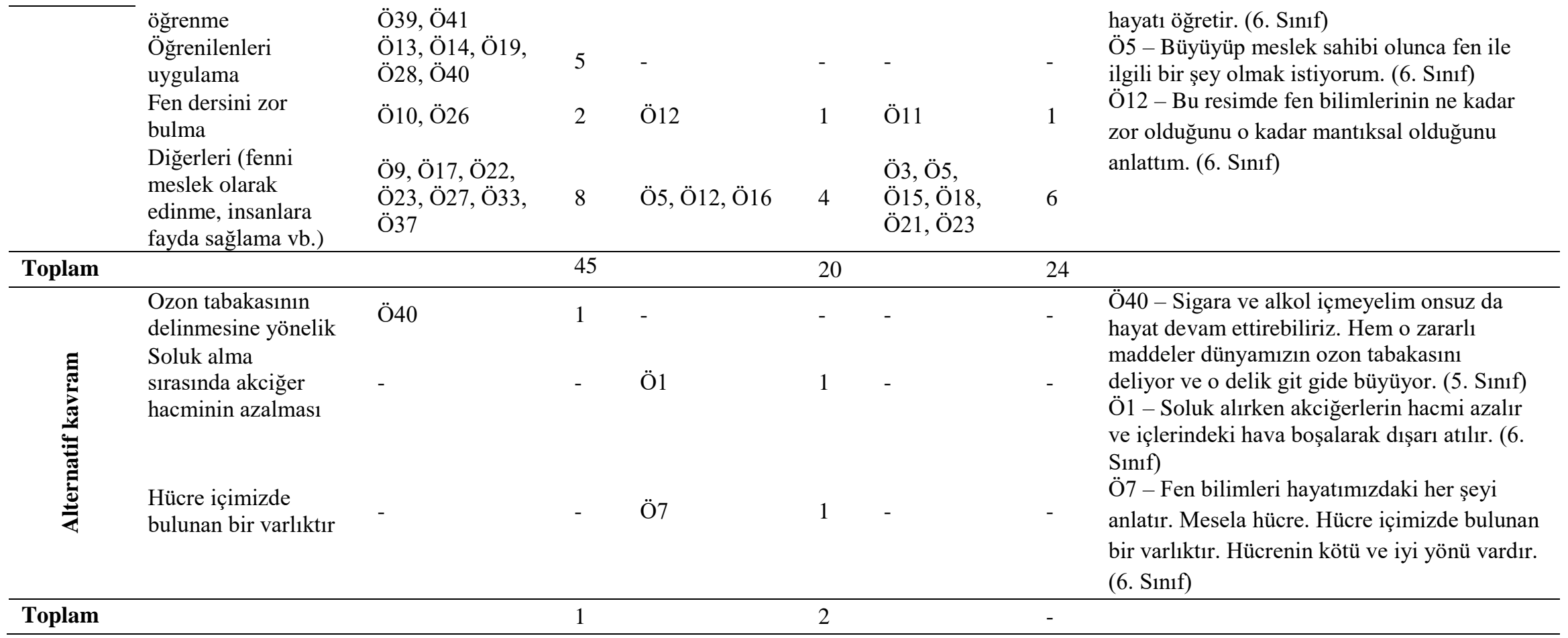


Tablo 2'ye bakıldığında, beşinci, altıncı ve yedinci sınıf öğrencilerinin yazılı açıklamalarının laboratuvar, öğrenme ortamı, konu alanı, duygu ve düşünceler ve alternatif kavramlar kategorileri altında toplandığı görülmektedir. Öğrencilerin çizimlerine yönelik olarak yaptıkları yazılı açıklamaların laboratuvar kategorisinde yoğunlaştığı görülmektedir. Bu kategoride beşinci sınıf seviyesinden 19, altıncı sınıf seviyesinden 8 ve yedinci sınıf seviyesinden 3 öğrenci deney yapma kodlarını içeren açıklamalar yaparken, bilim insanları kodu beşinci sınıftan 2, altıncı sınıftan 3 ve yedinci sınıftan 4 öğrenci tarafindan ifade edilmiştir. Bunun yanı sıra, beşinci sınıftan 6 öğrenci laboratuvar malzemeleri ile ilgili açıklamalar yapmıştır. Konu alanlarına yönelik yazılı açıklamaların beşinci sınıf düzeyinde kimya $(n=11)$, fizik $(n=8)$ ve biyoloji $(n=6)$ kodlarında sıralanırken, altıncı sınıf düzeyinde biyoloji $(n=7)$ ve fizik $(n=2)$ kodlarında, yedinci sınıf düzeyinde ise biyoloji $(n=10)$, kimya $(n=9)$ ve fizik $(n=7)$ kodları şeklinde sıralanmıştır.

Fen bilimlerine yönelik duygu ve düşünceler kategorisinde üç sınıf düzeyinde de ortak olarak ifade edilen 7 kodun (fenni sevme, dersi eğlenceli bulma, derse önem verme, fenni zor bulma, hayatla ilgili şeyler öğrenme, fenni meslek olarak edinme, insanlara fayda sağlama) açığa çıtığı görülmektedir. Örneğin, hayatla ilgili şeyler öğrenme koduyla ilgili beşinci sınıftan 3 , altıncı sınıftan 5 ve yedinci sınıftan 7 öğrencinin açıklamalar yaptı̆̆ görülürken, beşinci ve altıncı sınıftan 4'er ve yedinci sınıftan 6 öğrencinin açıklamalarında derse önem verme koduyla ilgili açıklamalar yaptıkları belirlenmiştir. Ayrıca, fenni sevme koduna yönelik 11 beşinci sınıf, 3 altıncı sınıf ve 1 yedinci sınıf öğrencisinin açıklamalar yaptığı görülmüştür.

Her ne kadar öğrencilerin çizimlerinde tespit edilemese de, yazılı açıklamalarında bazı alternatif kavramlara sahip oldukları görülmüştür (Tablo 2). Beşinci sınıf düzeyindeki Ö40 çiziminde sadece sigara ve alkolün zararlı olduğu ifade ederken, yazılı açıklamasında sigara ve alkolün ozon tabakasının delinmesine sebep olduğunu düşündüğünü belirtmiştir. Altıncı sınıf düzeyindeki Ö1 bir insan modeli üzerinden soluk alıp verme olayını çizerken, yazılı açıklamasında soluk alma sırasında akciğerin hacminin azaldığını ifade etmiştir. Ö7 ise pek çok konuya yönelik imgeler kullanırken, yazılı açıklamasında hücrenin bir varlık olduğunu, iyi ve kötü yönlerinin bulunduğunu ifade etmiştir. Beşinci, altıncı ve yedinci sınıf öğrencilerinin fen bilimleri dersine yönelik çizimlerindeki yüzde değişimler Grafik 1'de, yazılı açıklamalarındaki yüzde değişimler ise Grafik 2'de verilmiştir.

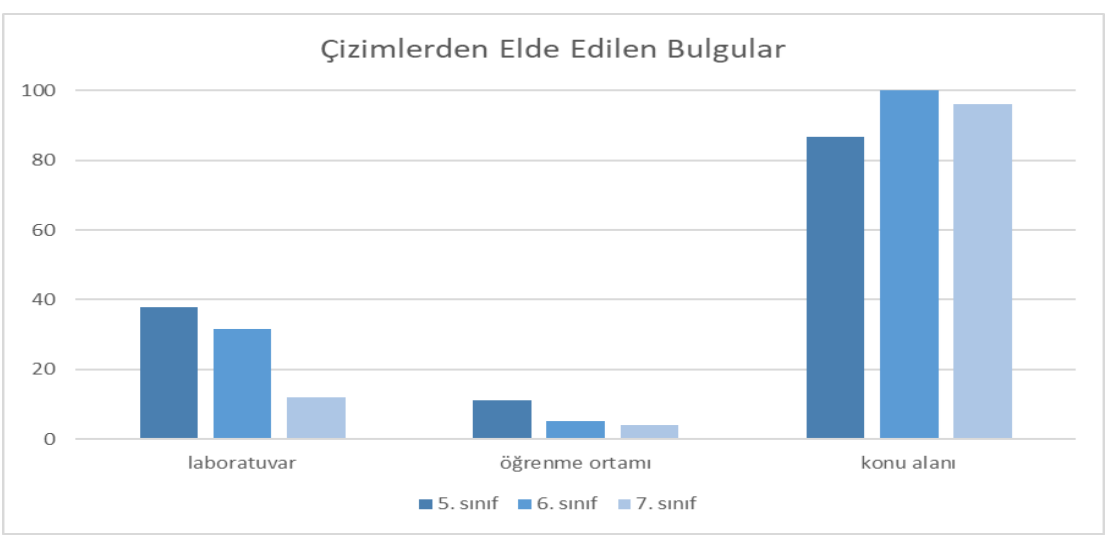

Grafik 1. Beşinci, altıncı ve yedinci sınıf öğrencilerinin çizimleri 


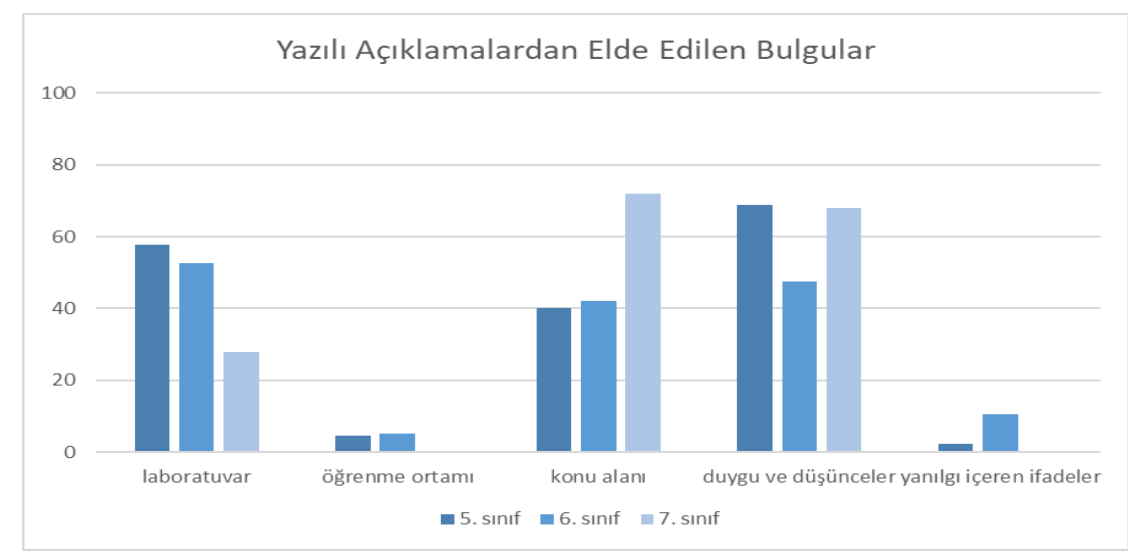

Grafik 2. Beşinci, altıncı ve yedinci sınıf öğrencilerinin yazılı açıklamaları

Grafik 1 ve Grafik 2'den görüldüğü gibi, öğrencilerin çizimlerinde laboratuvar, öğrenme ortamı ve konu alanı kategorileri açığa çıkarken, yazılı açıklamalarda bu kategorilerin yanı sıra duygu ve düşünceler ve alternatif kavram içeren ifadeler kategorilerine uygun açıklamaların yapıldığı belirlenmiştir. Öğrenci çizimlerinde konu alanı kategorisine uygun imajların diğer kategorilere kıyasla daha fazla açığa çıktığı görülürken, yazılı açıklamalarda konu alanı ve duygu ve düşünceler kategorilerine uygun ifadelerin yoğunluklu olarak yer aldığı tespit edilmiştir. Sınıf düzeyleri dikkate alınarak değerlendirildiğinde, beşinci sınıf öğrencilerinin çizimlerinde ve yazılı açıklamalarında laboratuvar, konu alanı ve duygu ve düşünceler kategorilerine, altıncı sınıf öğrencilerinin konu alanı ve yedinci sınıf öğrencilerinin konu alanı ve duygu ve düşünceler kategorilerine odaklandıkları görülmüştür. Bunların yanı sıra, beşinci ve altı sınıf düzeylerinden az sayıda öğrencinin yazılı açıklamalarında alternatif kavram içeren düşüncelere sahip oldukları tespit edilmiştir.

\section{Tartışma ve Sonuçlar}

Beşinci, altıncı ve yedinci sınıf öğrencilerinin fen bilimleri dersine yönelik görüşlerinin çizimler aracılı̆̆ıyla belirlenmesi amacıyla yürütülen bu çalışmada, öğrencilerin sınıf seviyesine göre eğilimlerinde farklılıklar oluştuğu görülmüştür. Laboratuvar ortamı ve laboratuvarda gerçekleştirilen uygulamalara yönelik çizimlere beşinci ve altıncı sınıf öğrencileri odaklanırken, yedinci sınıf öğrencilerinin bu kategoriye yönelik diğer sınıf düzeylerine kıyasla daha az çizim yaptıkları görülmüştür. Benzer durum öğrencilerin yazılı açıklamalarında da ortaya çıkmıştır. $\mathrm{Bu}$ durumun sebebinin, sınıf düzeyi arttıkça ders içeriklerinin yoğunlaşması, laboratuvar uygulamalarının yerine konuların teorik ve matematiksel boyutlarının ön plana çıkması ve öğrencilerin sınav ve gelecek kaygılarının artmasıyla ilgili olabileceği düşünülmektedir (Soysal ve Afacan, 2012). Grafik 1'e bakıldığında, tüm sınıf düzeylerinin konu alanı kategorisine yönelik çizimlere yoğun bir şekilde odaklandıkları görülmektedir. Bu kategoriye yönelik yazılı açıklamalarda ise yedinci sınıf öğrencilerinin diğer seviyelere kıyasla daha fazla yorum yaptıkları belirlenmiştir. Buradan, beşinci ve altıncı sınıf öğrencilerinin düşüncelerini ortaya koyarken çizime odaklanıp daha fazla imge kullandıkları, yazılı açıklamalara ise çizimlere göre nispeten daha az yer verdikleri görülmektedir. Buna karşın, yedinci sınıf öğrencilerinin düşüncelerini açıklarken imgelemeler yerine daha fazla yazılı açıklama yapma eğiliminde 
oldukları sonucuna ulaşılmıştır. Bu durumun sebebi, yaş seviyesi arttıkça öğrencilerin çizim yapmayı duygu ve düşüncelerini ifade etmek için yeterli ve etkili görmemelerinden kaynaklanabilir. Nitekim Rodari (2007) tarafından yürütülen çalışmada da 12 yaş üzerindeki öğrencilerin bir konuya yönelik duygu ve düşüncelerini ifade etmede çizimlerden çok yazılı ve sözlü açıklamalar yapma eğiliminde oldukları ifade edilmektedir. Diğer yandan, Tablo 1'e bakıldığında, beşinci sınıf öğrencilerinin kimya, altıncı sınıf öğrencilerinin biyoloji ve yedinci sınıf öğrencilerinin kimya ve biyoloji konu alanlarına, Tablo 2'de ise, yazılı açıklamalarda beşinci sınıf öğrencilerinin kimya, altıncı ve yedinci sınıf öğrencilerinin biyoloji konu alanına odaklandıkları görülmektedir. Bu bulgular beşinci sınıf öğrencilerinin çizimlerini destekleyecek niteliktedir. Beşinci sınıf öğrencilerinin özellikle kimya konu alanına odaklanmaları, fen bilimleri dersini okul ve laboratuvar ortamı dışında düşünmediklerinin ve fen bilimleri dersine yönelik sınırlı yaşantı geçirmiş olmalarının göstergesi olarak kabul edilebilir (Ballıel-Ünal, 2017; Kavak, 2008). Bu durum aynı zamanda, laboratuvar ortamında en fazla kimya alanına yönelik deneyler yapılması ve bu süreçte yoğun biçimde kullanılan laboratuvar malzemelerini resmetmek istemelerine sebep olmuş olabilir. Diğer yandan, uygulamanın gerçekleştirildiği tarihlerde işledikleri fen konularının da öğrencilerin odak noktalarını değiştirmiş olabileceği düşünülmektedir. Laboratuvar, öğrenme ortamı ve konu alanı kategorilerinin yanı sıra öğrencilerin yazılı açıklamalarında fen bilimleri dersine yönelik duygu ve düşüncelerini ifade ettikleri bir kategori daha açığa çıkmıştır. Bu kategori altındaki kodlara bakıldığında, üç sınıf düzeyinde de öğrencilerin fen dersini sevdiklerini ve eğlenceli bulduklarını ifade ettikleri görülmüştür. Öğrencilerin aynı zamanda, hayatla ilgili şeyler öğrenme, yeni bilgiler edinme, doğayı anlama, bilim insanı gibi hissetme, öğrenilenleri uygulama, bilgileri yorumlama ve anlamlandırma gibi faydalarının olduğunu düşünmeleri derse ilgi duymalarını sağlayabilir. Öğrencilerin aynı zamanda fenne ilgi ve merak duymaları, bu derste öğrendikleri bilgilerin günlük yaşamın bir parçası olmasıyla ve günlük yaşam durumlarını da dersle birlikte öğrenmeleriyle ilgili olabilir (Gürdal, 1992; Yenice, Saydam ve Telli, 2012). Diğer yandan, öğrencilerin çizimlerine bakıldığında, sadece 2 öğrencinin fen bilimleri dersini günlük hayatla ilişkilendirdiği çizim yaptığ 1 belirlenmiştir. $\mathrm{Bu}$ durumun sebebi, öğrencilerin yazılı açıklamalarında günlük hayatla ilgili bilgiler edindikleri, bu nedenle derse ilgi ve merak duyduklarını ifade etseler de edindikleri bilgilerin zihinlerindeki yansımalarının ders kapsamında yapılan uygulamaların, çevrelerindeki uyaranların ve ders kitaplarında ve eğitim kurumlarında verilen bilgilerin ötesine geçemediği şeklinde yorumlanabilir (Dönmez, 2017). Bu noktada, öğrenciler fen bilimlerinin günlük hayatla ilişkisinin ve bu bağlamdaki öneminin farkında olsalar da dersi günlük hayatla ilişkilendirme konusunda yeterli bilgi ve beceriye sahip olmadıkları düşünülebilir. Bunun yanı sıra, genel anlamda tüm sınıf düzeylerindeki öğrencilerin bir kısmının dersi zor bulduklarını ifade ettikleri görülmüştür. Derse önem verme, sınav, matematiksel işlemler gibi kodların da açığa çıkmış olması bazı öğrencilerin fen dersine önyargıyla yaklaşmalarının sebebi olabilir (Akıncı, Uzun ve Kışoğlu, 2015; Balbağ, Leblebicier, Karaer, Sarıkahya ve Erkan, 2016; Taber, 2002). Buna ek olarak, ailelerin fen bilimleri ve matematik gibi derslere daha fazla önem veriyor olmaları öğrencilerin dersi önemli bulmalarını sağlarken, bu derslerde başarısız olmaktan korkmalarını ve baskı altında hissetmelerini tetikleyebilir. Beşinci ve altıncı sınıf öğrencilerinin bir kısmının deney yapmaya ve bireysel çalışmaya yönelik çizimler yapmaları öğretmenlerinin ders sürecinde gösteri deneyi yapıyor olmasıyla ilişkili olabilir. Diğer yandan, bu sınıf düzeylerindeki bazı öğrencilerin bilim insanı figürünü resmetmeleri ve bilim insanını bireysel çalışmalar yürütürken çizmeleri de öğrencilerin 
bilimle uğraşan insanların grup çalışmalarındansa tek başına çalıştıklarını ve araştırmalarını yalnız yürüttüklerini düşünmelerinden kaynaklanabilir. Fen bilimleri ders kitaplarında bilim insanlarının bireysel olarak çalıştıklarının resmedilmesi de bu durumu pekiştiriyor olabilir (Karaçam, Aydın ve Digilli, 2014). Alanyazında, çeşitli sınıf düzeylerinden öğrencilerin çeşitli kaynaklardan bilim insanlarının tek başlarına çalıştıklarına yönelik çıkarımlarda bulundukları ifade edilmektedir (Karaçam, 2016; McAdam, 1990). Çalışmaya katılan öğrencilerin de bu kalıp yargıları edindikleri ve çizimlerinde bu durumu resmettikleri çıkarımında bulunulabilir. Buna paralel olarak, bazı öğrenciler yazılı açıklamalarında fen alanıyla ilişkili mesleklere yönelmek istedikleri belirtmişlerdir. Bu yaş grubundaki öğrencilerin okul içi uygulamalardan ziyade fen alanına mesleki açıdan bakmaları bu durumun sebebi olabilir (Kavak, 2008).

Öğrencilerin çizimlerinde çoğunlukla deney tüpü gibi laboratuvar malzemelerine yer vermeleri bilim insanına yönelik basmakalıp düşüncelerden biri olarak kabul edilebilir (Kara ve Akarsu, 2013; Mead ve Metraux, 1957; Nuhoğlu ve Afacan, 2007). Öğrencilerin fen bilimleri öğretmenini, bilginin kaynağı olan ve her şeyi bilen bir kişi olarak değil, bir bilim insanı gibi araştıran, sorgulayan, deneyler yaparak bilgiye ulaşan ve öğrenmeye devam eden bir kişi olarak görmeleri de bu durumun göstergesi olarak görülebilir (Dönmez, 2017). Aynı zamanda, bu cisimleri çizmek öğrenciler için daha kolay olabilir. Altıncı sınıf öğrencilerinin çizimlerine bakıldığında, öğrencilerin büyük kısmının kimyanın yanı sıra biyoloji alanına yönelik çizimler yaptıkları görülürken, yedinci sınıf öğrencilerinin kimya ve biyoloji alanlarına ek olarak fizik ile ilgili çizimler yapma eğiliminde oldukları görülmüştür. Yaptıkları çizimlerin daha çok soyut kavramlarla ilgili olduğu göz önünde bulundurulduğunda, bu durum, öğrencilerin bilişsel gelişim süreçlerinde somut işlemlerden soyut işlemler dönemine geçişlerinin bir yansıması olarak kabul edilebilir.

Öğrencilerin çizimlerinde alternatif kavrama rastlanmasa da, kendi çizimlerine yönelik yazılı açıklamalarında alternatif kavram içeren açıklamalara yer verdikleri ortaya çıkmıştır (Bkz. Tablo 2). Bu durum çizimlerin alternatif kavramların tespit edilmesinde tek başına yeterli olmayacağı görüşünü desteklemektedir (White ve Gunstone, 1992). Dolayısıyla, çizimlerin başka bir metotla desteklenmesi (yazılı ya da sözel açıklama gibi) derinlemesine bilgi elde edilmesi adına önem arz etmektedir.

\section{Öneriler}

Öğrencilerin fen bilimleri dersine yönelik algılarının çizimler aracılığıyla açığa çıkarılmasının amaçlandığı bu çalışmada, öğrencilerin fen konu alanları, bilim insanları, öğretmen, öğrenme ortamı, derse yönelik duygu ve düşünceler gibi pek çok boyutla dersi ilişkilendirdikleri belirlenmiştir. Çizim yöntemiyle öğrencilerin düşüncelerini özgürce ve herhangi bir kısitlamayla karşılaşmadan ifade edebilmelerinin bu boyutların açığa çıkmasını sağladığı düşünüldüğünde, öğrencilerin bilişsel düzeyleri kadar içsel durumlarının, motivasyonlarının ve yaşadıkları sorunların belirlenmesinde çizimlerden faydalanmanın önemli sonuçlar vereceği düşünülmektedir. Bunun yanı sıra, çizim yöntemi aracılığıyla yürütülecek çalışmalarda öğrencilerin çizimlerine yönelik yazılı açıklamalarının da alınması hem çizimlerin doğru biçimde yorumlanması hem de öğrencilerin araştırılan konuya yönelik görüşlerinin bütünüyle açığa çıkarılması açısından önemli görülmektedir. Bu tür çalışmalarla elde edilecek verilerin öğrencilerin derse yönelik kaygıları, öğrenme ortamından beklentileri ya da geleceğe yönelik kariyer planlarının şekillendirilmesinde öğretmenlere rehberlik edeceği düşünülmektedir. 
Öğretmenlerin bu yolla, öğrencilerinin fenne yönelik bakış açıları, önyargıları, kaygıları ve beklentileri hakkında yazılı ve sözlü açıklamalara kıyasla çizimler aracılığıyla çok daha gerçekçi ve derinlemesine bilgi elde edebileceklerine inanılmaktadır. Bu sayede, öğrenme ortamlarını öğrencilerinin ihtiyaçları ve beklentileri doğrultusunda tasarlayabilecekleri düşünülmektedir. $\mathrm{Bu}$ çalışma aynı zaman diliminde farklı sınıf düzeylerindeki öğrencilerle enlemsel olarak yürütülmüştür. Ancak, bahsi geçen etkileri daha gerçekçi bir bakış açısıyla gözlemleyebilmek için boylamsal çalışmaların yürütülmesi önerilmektedir. Aynı grup üzerinde yürütülecek böyle bir çalışma ile öğrenme ortamlarında yapılan düzenlemelerin gelişimsel olarak etkililiği hakkında daha doğru sonuçlar elde edilebilir. Buna paralel olarak, diğer derslerde de öğrenci algılarının çizimler aracılığıyla belirlenmesi ve elde edilen veriler doğrultusunda öğrenme ortamlarının ve süreçlerinin şekillendirilmesinin benzer etkiler yaratacağı düşünülmektedir. Ayrıca, bu tür çalışmaların kültürlerarası iş birliği ile yürütülmesi, farklı kültürdeki öğrenme ortamları ve bu ortamların öğrenciler üzerindeki olumlu ve olumsuz etkileri hakkında fikir verecektir. 


\section{Kaynakça}

Abraham, M. R., Williamson, V. M., \& Westbrook, S. L. (1994). A cross-age study of the understanding of five concepts. Journal of Research in Science Teaching, 31(2), 147- 165.

Akkus, H. (2013). Pre-service secondary science teachers' images about themselves as science teachers. Journal of Baltic Science Education, 12(2), 249-260.

Akınc1, B., Uzun, N. ve Kışoğlu, M. (2015). Fen bilimleri öğretmenlerinin meslekte karşılaştıkları problemler ve fen ögretiminde yaşadıkları zorluklar. International Journal of Human Sciences, 12(1), 1189-1215.

Alkış-Küçükaydın, M. ve Uluçınar-Sağır, Ş. (2018). Okul öncesi öğretmenliği öğretmen adaylarının fen öğretimine yönelik zihinsel imajları ve yöntem-teknik yaklaşımları. Hacettepe Üniversitesi Eğitim Fakültesi Dergisi, 33(4), 953-966. doi: 10.16986/HUJE.2018037332

Aydoğdu, M. ve Kesercioğlu, T. (2005). Illköğretimde fen ve teknoloji öğretimi. Ankara: Anı Yayıncılık.

Bahar, M., Ozel, M., Prokop, P., \& Usak, M. (2008). Science student teachers' ideas of the heart. Journal of Baltic Science Education, 7(2), 78-85.

Balbağ, M. Z., Leblebicier, K., Karaer, G., Sarıkahya, E. ve Erkan, Ö. (2016). Türkiye'de fen eğitimi ve öğretimi sorunları. Ĕgitim ve Öğretim Araştırmaları Dergisi, 5(3), 12- 23.

Balliel-Ünal, B. (2017). Analysis of perceptions of primary school students towards science using the pictures they draw İlkokul öğrencilerinin fen bilgisine yönelik algılarının çizdikleri resimlerle analizi. Journal of Human Sciences, 14(3), 3031-3043.

Barraza, L., \& Robottom, I. (2008). Gaining representations of childiren's and adults' constructions of sustainability issues, International Journal of Environmental and Science Education, 3(4), 179191.

Belet Ş. D. ve Türkan, B. (2007). İlköğretim öğrencilerinin yazılı anlatım ve resimsel ifadelerinde alg1 ve gözlemelerini ifade biçimleri (Avrupa birliği örneği). VI. Ulusal Sinıf Öğretmenliği Ĕğitimi Sетроzуити içinde (s. 270-278). Ankara: Nobel Yayın Dağıtım.

Chula, M. (1998, April). Adolescents' drawings: a view of their worlds. Paper presented at the Annual Meeting of the American Educational Research Association, San Diego, CA.

Çalık, M., Ültay, N., Kolomuç, A., \& Aytar, A. (2015). A cross-age study of science student teachers' chemistry attitudes. Chemistry Education Research and Practice, 16(2), 228-236.

Çalık, M., Turan, B., \& Coll, R. K. (2014). A cross-age study of elementary student teachers'scientific habits of mind concerning socioscientific issues. International Journal of Science and Mathematics Education, 12(6), 1315-1340.

Çavdar, O., Okumuş, S., \& Doymuş, K. (2016). Fen eğitimi öğrencilerinin maddenin tanecikli yapısıyla ilgili anlamalarının belirlenmesi. Mustafa Kemal Üniversitesi Sosyal Bilimler Enstitüsü Dergisi, 13(33), 69-93.

Çepni, S. (2014). Araştırma ve proje çalışmalarına giriş (7. baskı). Celepler Matbacılık:Trabzon.

Devecioğlu, Y. ve Akdeniz, A. R. (2006). Fizik öğretmen adaylarının alan bilgilerini günlük yaşamla ilişsilendirme düzeyleri. VII. Ulusal Fen Bilimleri ve Matematik Eğitimi Kongresi'nde sunulan bildiri, Gazi Üniversitesi, Ankara.

Dikmenli, M. (2010). Misconceptions of cell division held by student teachers in biology: A drawing analysis. Scientific Research and Essays, 5(2), 235-247. 
Doğan, M., Oruncak, B., \& Günbayı, İ. (2002). Teachers and students' approach to the problems in physics education at high school level, Physics Education, 37, 543-546.

Dönmez, G. (2017). Ortaokul ögrrencilerinin fen bilimleri dersine, bilime, fen bilimleri öğretmenine ve bilim insanına yönelik metaforik algıları ve imajları (Yayınlanmamış yüksek lisans tezi). Adnan Menderes Üniversitesi, Fen Bilimleri Enstitüsü, Aydın.

Driver, R. (1989). Students' conceptions and the learning of science. International Journal of Science Education, 11(5), 481-490.

Dülger, D. (2002). 12-14 yaş arası uyumsuz öğrencilerin resim etkinlikleri yolu ile duygularını ifade etmeleri ve analizi (Yayımlanmamış yüksek lisans tezi). Selçuk Üniversitesi, Sosyal Bilimler Enstitüsü, Konya.

Efland, A. D. (1995). Change in the conceptions of art teaching. In Neperud, R. (ed.) Context, content, and community in art education beyond postmodernism (pp. 25-40). NY: Teachers College Press.

Einarsdottir, J., Dockett, S., \& Perry, B. (2009). Making meaning: Children's perspectives expressed through drawings. Early child development and care, 179(2), 217-232.

Elmas, R., Demirdöğen, B., \& Geban, Ö. (2011). Preservice chemistry teachers' images about science teaching in their future classrooms. Hacettepe Üniversitesi Ĕgitim Fakültesi Dergisi, 40(40), 164175.

Eyceyurt-Türk, G., Akkuş, H. ve Tüzün, Ü. N. (2014). Fen bilgisi öğretmen adaylarının çözünme ile ilgili imajları. Erzincan Üniversitesi Eğitim Fakültesi Dergisi, 16(2), 65-84.

Glynn, S. (1997). Drawing mental models. The Science Teacher, 64(1), 30.

Gökdere, M., \& Çalik, M. (2010). A cross-age study of Turkish students' mental models: An "Atom" concept. Didactica Slovenica-Pedagoska Obzorja, 25(2), 185-199.

Gülek, C. (1999, April). Using multiple means of inquiry to gain insight into classrooms: a multi-trait multi-method approach. Paper presented at the Annual Meeting of the American Educational Research Association, Montreal, Canada.

Gürdal, A. (1992). İlköğretim okullarında fen bilgisinin önemi. Hacettepe Üniversitesi Eğitim Fakültesi Dergisi, 8(8), 185-188.

Haney, W., Russell, M., \& Bebell, D. (2004). Drawing on education: Using drawings to document schooling and support change. Harvard Educational Review, 74(3), 241-272.

Harman, G., Aksan, Z., \& Çelikler, D. (2015). Mental models which influence the attitudes of science students towards recycling. International Journal of Sustainable and Green Energy, 4(1-2), 6-11. doi: $10.11648 /$ j.jirse.s.2015040102.12

Isbell, R.T., \& Raines S.C. (2003). Creativity and the arts with young children. Canada: Thomson Delmar Learning Printed.

Kaplan, M. (2011). İlköğretim öğrencilerinin fen ve teknoloji dersi öğrenme ve öğretme ortamına yönelik düşünceleri. Eğitim Ve İnsani Bilimler Dergisi: Teori Ve Uygulama, (4), 77-92.

Kara, B., \& Akarsu, B. (2013). Ortaokul öğrencilerinin bilim insanına yönelik tutum ve imajının belirlenmesi. Journal of European Education, 3(1), 8-15.

Karaçam, S., Aydın, F. ve Digilli, A. (2014). Fen ders kitaplarında sunulan bilim insanlarının basmakalıp bilim insanı imajı açısından değerlendirilmesi. Ondokuz Mayıs Üniversitesi Eğitim Fakültesi Dergisi, 33(2), 606-627. 
Karaçam, S. (2016). Scientist-image stereotypes: the relationships among their indicators. educational sciences: Theory and Practice, 16(3), 1027-1049.

Kızılcık, H. Ş. (2013). Öğretmen adaylarının bazı eş anlamlı fizik terimleri arasındaki tercihlerinin kavramsal algılamayla ilişkisi. Hacettepe Üniversitesi Eğitim Fakültesi Dergisi, 28(3), 266-278.

Kibar-Kavak, G. (2008). Öğrencilerin bilime ve bilim insanına yönelik tutumlarını ve imajlarını etkileyen faktörler (Yayınlanmamış yüksek lisans tezi). Selçuk Üniversitesi, Sosyal Bilimler Enstitüsü, Konya.

Malchiodi, C.A. (2005). Çocukların resimlerini anlamak (Yurtbay, T., Çev.) İstanbul: Epsilon.

McAdam, J. E. (1990). The persistent stereotype: Children's images of scientists. Physics Education, $25(2), 102$.

Mead, M., \& Metraux, R. (1957). Image of the scientist among high-school students. Science, 126(3270), 384-390.

Melanlığlu, D. (2015). Ortaokul öğrencilerinin Türkçe dersi algılarına yönelik yaptıkları çizimler. Okuma Yazma Eğitimi Araştırmaları, 3(1), 27-38.

Mercer, N., Dawes, L., \& Staarman, J. K. (2009). Dialogic teaching in the primary science classroom. Language and Education, 23(4), 353-369.

Miles, M. B. \& Huberman, A. M. (2015). Nitel veri analizi. (Akbaba, S. ve Ersoy, A. A., Çev.). Ankara: Pegem Akademi.

Nuhoğlu, H. ve Afacan, Ö. (2007). İlköğretim öğrencilerinin bilim insanına yönelik düşüncelerinin değerlendirilmesi, 16. Ulusal Eğitim Bilimleri Kongresi'nde sunulan bildiri, Tokat.

Nyachwaya, J. M., Mohamed, A. R., Roehrig, G. H., Wood, N. B., Kern, A. L., \& Schneider, J. L. (2011). The development of an open-ended drawing tool: An alternative diagnostic tool for assessing students' understanding of the particulate nature of matter. Chemistry Education Research and Practice, 12(2), 121-132.

Oruncak, B., Ünal, R. ve Özek, N. (2004). Sinıf Öğretmeni Adaylarının Fizik Dersine Baklşı. Türk Fizik Derneği 22. Fizik Kongresi'nde sunulan bildiri, Bodrum.

Özdemir-Özden, D. ve Özden, M. (2015). Çevre sorunlarına ilişkin öğrenci çizimlerinin incelenmesi. Pamukkale Üniversitesi Eğitim Fakültesi Dergisi, 37(1), 1-20.

Özmen, H. (2005). Kimya öğretiminde yanlış kavramlar: Bir literatür araştırması. Gazi Üniversitesi Türk Eğitim Bilimleri Dergisi, 3(1), 23-45.

Pekel, F. ve Taştan-Kırık, Ö. (2016). Ortaokul öğrencilerinin küresel ısınma ve ozon tabakasının incelmesi konularındaki bilişsel yapıları. Eğitimde Kuram ve Uygulama, 12(1), 308-357.

Rodari, P. (2007). Science and scientists in the drawings of European children. Journal of Science Communication, 6(3), 1-12.

Sadık, F., Çakan, H. ve Artut, K. (2011). Çocuk resimlerine yansıyan çevre sorunlarının sosyo-ekonomik farklılıklara göre analizi. İlköğretim Online, 10(3), 1066-1080.

Soysal, D. ve Afacan, Ö. (2012). İlköğretim öğrencilerinin "fen ve teknoloji dersi" ve "fen ve teknoloji öğretmeni" kavramlarına yönelik metafor durumları. Mustafa Kemal Üniversitesi Sosyal Bilimler Enstitüsü Dergisi, 9(19), 287-306.

Taber, K. (2002). Chemical misconceptions: Prevention, diagnosis and cure. Volume 1: Theoretical background. London: Royal Society of Chemistry. 
Toplu, H. (2015). 8. sinıf öğrencilerinin fen ve teknoloji dersine yönelik metaforik algıları (Yayınlanmamış yüksek lisans tezi). Hacettepe Üniversitesi, Eğitim Bilimleri Enstitüsü, Ankara.

Ulu, H. (2012). İlköğretim öğrencilerinin fen öğretimine yönelik algılarına bazı değişkenlerin etkisi (Yayınlanmamış yüksek lisans tezi). Afyon Kocatepe Üniversitesi, Sosyal Bilimler Enstitüsü, Afyon.

Uzunkavak, M. (2009). Öğrencilerin iş kavramında pozitiflik-negatiflik ayrımı becerilerinin yazı ve çizim metoduyla ortaya çıkarılması. International Journal of Technologic Sciences, 1(2), 10-20.

Welch, N., \& Greene, A. (1995). Schools, communities and the arts: A research compendium. Washington, DC: National Endowment for the Arts.

Yavuzer, H. (2003). Çocuğu tanımak ve anlamak (6. Baskı). İstanbul: Remzi Kitabevi.

Yenice, N., Saydam, G. ve Telli, S. (2012). İlköğretim öğrencilerinin fen öğrenmeye yönelik motivasyonlarını etkileyen faktörlerin belirlenmesi. Ahi Evran Üniversitesi Kırşehir Eğitim Fakültesi Dergisi, 13(2), 231-247.

Yıldız-Feyzioğlu, E., Feyzioğlu, B. ve Küçükçıng1, A. (2014). Fen bilgisi öğretmen adaylarının fen öğretimine yönelik zihinsel modelleri, öz yeterlik inançları ve öğrenme yaklaşımları. Ondokuz Mayıs Üniversitesi Ĕ̆itim Fakültesi Dergisi, 33(2), 404-423.

Zians, A. W. (1997). A qualitative analysis of how experts use and interpret the kinetic school drawing technique. Unpublished master thesis, University of Toronto, Canada. 


\section{Extended Abstract}

\section{Introduction}

Students may bring various prejudices of the course to learning environment(s). For this reason, learning environments should be designed to allow students to overcome their prejudices. On the other hand, their communication and interaction skills/levels with the learning environment(s) are also very important for organizing their learning and teaching environments. Unveiling their perceptions and views of their own teachers, friends, classes and learning environments will contribute to develop their learning experiences. In particular, understanding their views and difficulties of the science course may serve as a crucial basis for creating an effective communication with them. If teachers are good at communicating with their students, will have opportunities to understand their problems and create proper problem-solving strategies.

Drawings, as an open-ended questioning approach, enable students to easily express themselves without restricting their ideas/views with words. That is, students can freely reveal their knowledge, views and beliefs with the drawings. After drawings, verbal or written explanations may provide important in-depth insights about what they meant by the drawings. Thus, it is believed that determining students' views is important for getting more insights of their learning environments. In this context, the aim of this study was to unveil the fifth, sixth and seventh grade students' mental images of the science course through drawings and writings.

\section{Method}

Because cross-age studies allow to examine the same behaviors/issues through similar groups in a short particular time (i.e., one-time interaction) as compared with longitudinal ones, the current study preferred carrying out a cross-age study. A total of 79 students (45 for grade 5, 19 for grade 6 and 25 for grade 7), who were selected via convenient sampling method, took part in the current study during spring semester of the 2015 - 2016 academic year.

Two researchers independently analyzed their drawings and written explanations of the science course and thematically grouped them as specific themes and codes. Inter-rater reliability coefficient was found to be .96 . Their frequencies were presented in tables.

\section{Findings}

The findings pointed that the fifth, sixth and seventh grade students' mental images were labelled under the "laboratory, learning environment and subject area" categories. For the "subject area" category, the fifth-grade students' drawings focused on chemistry. Also, frequency of the students' drawings related to biology was very low in comparison to chemistry. The sixth and seventh grade students' drawings mostly referred to biology and chemistry. For the "laboratory" category, the fifth-grade students' drawings included experiments and individual laboratory studies, whilst minority of the sixth and seventh grade students' drawings was classified in this category.

The findings concerning written explanations were categorized under the "laboratory, learning environment, subject area, emotions and course thoughts and misconceptions" categories. Their written explanations generally fell into the "laboratory" category. For the subject areas, the fifth and seventh grade students' written explanations contained "chemistry, 
physics and biology" codes, whereas, the sixth-grade students incorporated "biology and physics" codes. The "science-related emotions and thoughts" consisted of seven common codes (i.e., liking science course, enjoying science course, the importance of science course, learning it difficult, life-related learning) for all grades.

\section{Discussion and Conclusions}

The findings revealed the students from varied grades had different tendencies for the science course. For example; the fifth and sixth grade students' drawings focused on the "laboratory and laboratory practice" codes, while few seventh-grade students cited to these codes in their drawings. Similar case was valid for their written explanations. Moreover, the fact that the seventh-grade students' drawings were more related to abstract science concepts may stem from their cognitive development processes (e.g., from concrete operational stage to formal operational stage). Even though some students' written explanations embraced their interest in the science course and their learning about daily life, none of them handled these daily life dimensions of the science course within their drawings. This means that they may have difficulties at transferring their gained knowledge to daily life. Besides, the fact that some students found the science course difficult may result from their prejudices of the science course.

\section{Recommendations}

Since this study probed their mental images of the science course, future studies may use the drawing method affording students express their thoughts freely and without any word limitation. In this context, further studies should employ the drawing method to identify their worldviews, learning motivation and problems as well as their cognitive learning. By doing this, teachers may design their learning and teaching environments to meet students' needs and expectations. Moreover, cross-cultural studies should be undertaken to find how different cultures positively or negative influence students' views of learning environments. 